\title{
LACTOBACILLUS BULGARICUS SEBAGAI PROBIOTIK GUNA PENINGKATAN KUALITAS AMPAS TAHU UNTUK PAKAN CACING TANAH
}

\author{
Purkan Purkan, Nur Nisdiyatul Laila, Sri Sumarsih \\ Prodi S-1 Kimia, Departemen Kimia, Fakultas Sains dan Teknologi, \\ Universitas Airlangga, Surabaya \\ email:purkan@fst.unair.ac.id
}

Received 20 Pebuari 2017 Accepted 20 April 2017

\begin{abstract}
Abstrak
Penelitian ini bertujuan untuk menentukan aktivitas protease dari probiotik Lactobacillus bulgaricus dan pengaruh probiotik Lactobacillus bulgaricus dalam fermentasi pakan ampas tahu untuk meningkatkan produktivitas cacing tanah. Metode yang digunakan untuk penentuan aktivitas protease dalam hidrolisis substrat kasein adalah metode Bradford. Dari hasil penelitian, probiotik Lactobacillus bulgaricus menghasilkan protease selama 18 jam pertumbuhan, dengan aktivitas protease sebesar 131,04 U/mL. Probiotik Lactobacillus bulgaricus OD 0,6 dapat menghidrolisis protein ampas tahu sebesar 1,48 $\mu \mathrm{g} / \mathrm{mL}$ dalam 12 jam fermentasi. Produktivitas cacing tanah mengalami peningkatan berat cacing tanah karena adanya pengaruh probiotik Lactobacillus bulgaricus pada pakan ampas tahu yang ditunjukkan dengan persen kenaikan berat cacing tanah sebesar 32,13\%.
\end{abstract}

Kata kunci: Probiotik, Lactobacillus bulgaricus, Enzim protease, Cacing tanah

\begin{abstract}
The aims of this study were to determine the protease activity of the Lactobacillus bulgaricus probiotic and to know the effect of tofu dregs feed fermentation in increment of the earthworms productivity. The Bradford method was used for determination of protease activity in the hydrolysis of casein substrate. From the research, the Lactobacillus bulgaricus probiotic released protease during 18 hours of growth and the protease activity was $131,04 \mathrm{U} / \mathrm{mL}$. Lactobacillus bulgaricus probiotic in $0.6 \mathrm{OD}$ could hydrolyze protein of tofu dregs as well as $1.48 \mu \mathrm{g} / \mathrm{mL}$ during 12 hours of fermentation. The earthworms productivity could increase the weight of earthworms due to the influence of Lactobacillus bulgaricus probiotic in tofu dregs feed, it was indicated by the increment of earthworms weight up to $32.13 \%$.
\end{abstract}

Keywords: Probiotics, Lactobacillus bulgaricus, protease enzyme, Earthworms

\section{Pendahuluan}

Probiotik merupakan mikroorganisme hidup yang memberikan manfaat bagi kesehatan dalam jumlah tertentu (FAO/WHO, 2001). Probiotik umumnya berasal dari golongan asam laktat seperti Lactobacillus bulgaricus. Lactobacillus bulgaricus memiliki peran penting di jalur intestinal karena dapat menjaga keseimbangan mikroflora sehingga tubuh tidak mudah terserang penyakit (Rahayu, 2002). Selain itu, Lactobacillus bulgaricus juga dimanfaatkan untuk berbagai produk fermentasi makanan. Probiotik mampu 
menguraikan rantai panjang karbohidrat dan protein karena adanya enzim tertentu dalam selnya yang dapat mengolah protein yang kompleks menjadi asam-asam amino yang lebih sederhana (Effendi, 2002). Enzim tersebut adalah protease.

Probiotik tidak hanya dimanfaatkan di bidang kesehatan dan makanan tetapi juga dibidang peternakan (Kompiang, 2009). Ternak yang paling mudah dilakukan treatmen adalah ternak cacing tanah. Cacing tanah dijadikan profit usaha yang menjanjikan di kalangan masyarakat karena penanganan dan produksi yang mudah. Untuk meningkatkan produksivitas cacing tanah, asupan pakan cacing tanah juga diperhatikan. Pakan cacing tanah berupa sampah rumah tangga seperti ampas tahu. Ampas tahu merupakan protein kompleks yang lebih sulit dicerna oleh usus cacing tanah dan tidak dapat bertahan lama. Hal ini menyebabkan banyaknya ampas tahu yang terbuang tanpa ada peningkatan produksi cacing tanah sehingga menimbulkan banyak kerugian finansial bagi peternak. Oleh karena itu perlu dilakukan penelitian mengenai Lactoacillus bulgaricus sebagai probiotik guna peningkatan kualitas ampas tahu untuk pakan cacing tanah.

\section{Metode Penelitian}

\section{Alat dan Bahan}

Perlatan yang digunakan terdiri atas gelas beker, hot plate, labu erlenmeyer, autoclave, tabung reaksi, rak tabung reaksi, kawat ose, bunsen, laminar air flow, lemari es, incubator, spektrofotometer UV-VIS, shaker incubator, cawan petri, pipet volume, pipet tetes, dan pengaduk. Sementara bahan utamanya adalah isolat Lactobacillus bulgaricus yang digunakan untuk prebiotik, diperoleh dari Laboratorium Mikrobiologi Departemen Biologi, Fakultas Sains dan Teknologi. Universitas Airlangga.. Spesimen yang akan diteliti berupa hewan hidup cacing tanah, diperoleh dari peternak cacing tanah di daearh Kamal, Madura.

\section{Prosedur}

Pembuatan media MRS broth.

Media cair MRS terdiri dari 1\% (b/v) pepton, $0,5 \%(\mathrm{~b} / \mathrm{v})$ yeast extract dan $2 \%$ (b/v) glukosa. Media disterilkan dengan autoklaf pada tekanan 1 atm, temperatur $121^{\circ} \mathrm{C}$ selama 15 menit.

\section{Pembuatan kurva pertumbuhan bakteri.}

Bakteri diperbanyak dengan cara ditumbuhkan pada media MRS broth. Sebanyak $2 \% \quad(\mathrm{v} / \mathrm{v})$ inokulum Lactobacillus bulgaricus dimasukkan kedalam $25 \mathrm{~mL}$ media MRS broth. Media yang berisi inokulum diinkubasi pada suhu ruang menggunakan alat shaker dengan kecepatan $130 \mathrm{rpm}$ selama 48 jam. Pada interval 4 jam dilakukan pengukuran nilai optical density (OD) menggunakan spektrofotometer UV-VIS pada $\lambda 600 \mathrm{~nm}$.

Panen protease ekstraseluler Lactobacilus bulgaricus.

Protease ekstraseluler didapatkan dari pemisahan antara sel bakteri dengan substrat (media biakan yang dicampur induser). Induser yang digunakan yaitu BSA dan ampas tahu. Sebanyak $25 \mathrm{~mL}$ MRS broth ditambahkan 2\% (v/v) inokulum Lactobacillus bulgaricus dan $1 \mathrm{~g}$ ampas tahu. Sedangkan media biakan yang lain, $25 \mathrm{~mL}$ MRS broth ditambahkan 2\% (v/v) inokulum Lactobacillus bulgaricus dan $1 \mathrm{~mL}$ BSA $1 \mu \mathrm{g} / \mathrm{mL}$. Masing-masing media dishaker pada suhu kamar selama 18 jam. Pada 0 jam dan 18 jam, dilakukan sentrifuge dengan kecepatan $9000 \mathrm{rpm}$ selama 10 menit untuk memperoleh protease ekstraseluler Lactobacillus bulgaricus. Supernatan yang diperoleh pada jam ke-18 dilakukan uji aktivitas protease (Enggel et al. 2004) dan penentuan kadar protein (Bradford, 1976).

\section{Uji aktivitas protease.}

Sebanyak $250 \quad \mu \mathrm{L}$ supernatan ditambahkan $250 \mu \mathrm{L}$ buffer fosfat $\mathrm{pH} 7$. Selanjutnya larutan diinkubasi selama 5 menit pada suhu $37^{\circ} \mathrm{C}$. Setelah diinkubasi, larutan ditambahkan $250 \mu \mathrm{L}$ substrat $(2 \%$ 
kasein dalam buffer fosfat $\mathrm{pH}$ 7). Larutan diinkubasi kembali selama 10 menit pada suhu $37^{\circ} \mathrm{C}$. Kemudian larutan ditambahkan $500 \mu \mathrm{L}$ asam trikloroasetat (TCA) 0,4 M. Larutan yang sudah mengendap, disentrifuge untuk memisahkan endapan dan supernatan. Supernatan yang diperoleh diukur nilai absorbansinya menggunakan metode Bradford, yang selanjutnya dapat dihitung kadar proteinnya (Enggel et al., 2004).

$$
\text { Unit/mL enzim }=\frac{(\text { kadar enzim })(\text { Vtot })}{(V)(t)} \times \text { Fp }
$$

Keterangan:

Vtot $=$ Volume total dalam analisis $(\mathrm{ml})$

$\mathrm{V}=$ Volume enzim yang digunakan (ml)

$\mathrm{t} \quad=$ Waktu analisis (menit)

$\mathrm{Fp}=$ Faktor pengenceran selama analisis

\section{Penentuan kadar protein.}

Sebanyak $100 \mu \mathrm{L}$ sampel di tambah dengan $5 \mathrm{~mL}$ Bradford dan $3 \mathrm{~mL}$ akuades. Larutan dihomogenkan hingga larut sempurna. Selanjutnya larutan diinkubasi pada suhu $37^{\circ} \mathrm{C}$ selama 5 menit. Kemudian larutan diukur nilai absorbansinya menggunakan spektrofotometer UV-VIS pada $\lambda 595 \mathrm{~nm}$. Kadar protein dalam suatu sampel ditentukan dengan memasukkan nilai absorbansi yang terbaca pada spektrofotometer kedalam persamaan regresi liner hasil ekstrapolasi kurva standar BSA (Bradford, 1976).

\section{Uji kinerja probiotik Lactobacillus} bulgaricus pada pakan ampas tahu.

Uji kinerja probiotik dilakukan dengan cara memfermentasi pakan ampas tahu dengan variasi optimasi konsentrasi dan waktu fermentasi probiotik. Optimasi konsentrasi probiotik dilakukan dengan cara menyiapkan 5 gelas beker yang berisi masing-masing $20 \mathrm{~g}$ ampas tahu yang dilarutkan dalam $20 \mathrm{~mL}$ akuades. Masingmasing wadah ditambahkan $25 \mathrm{~mL}$ suspensi probiotik OD 0,2;0,4;0,6;0,8 dan 1. Fermentasi dilakukan dengan menshaker masing-masing wadah pada suhu kamar selama 20 jam. Setiap interval
4 jam diamati sifat fisik dari ampas tahu yang meliputi perubahan tekstur, bau, dan warna. Selain itu, pada interval tersebut juga dilakukan sentrifugasi untuk memisahkan supernatan yang akan digunakan untuk penentuan kadar protein.

Uji kinerja probiotik Lactobacillus bulgaricus pada cacing tanah.

Kondisi optimum yang diperoleh dari konsentrasi probiotik dan waktu fermentasi probiotik, digunakan untuk melakukan uji kinerja probiotik Lactobacillus bulgaricus pada cacing tanah. Cacing tanah ditentukan beratnya terlebih dahulu. Selanjutnya, cacing tanah diberikan umpan berupa pakan ampas tahu yang dicampur dengan probiotik Lactobacillus bulgaricus. Pertumbuhannya diamati selama 16 hari. Setelah16 hari, cacing tanah ditimbang kembali untuk mengetahui berat cacing tanah setelah diberikan umpan probiotik.

\section{Hasil dan Pembahasan}

Kurva Pertumbuhan Lactobacillus bulgaricus.

Pola pertumbuhan Lactobacillus bulgaricus ditampilkan pada Gambar 1. Pertumbuhan mikroorganisme didefinisikan bertambahnya jumlah sel dari satu sel menjadi jutaan sel setelah terjadi pembelahan. Berdasarkan Gambar 1 dapat dijelaskan bahwa pola pertumbuhan bakteri Lactobacillus bulgaricus mengalami 4 fase yaitu fase lag, fase log (fase eksponensial), fase stasioner dan fase kematian. Fase lag merupakan fase adaptasi bakteri untuk mulai tumbuh pada media yang baru, sehingga pada fase ini belum terjadi peningkatan sel. Fase lag terjadi pada jam ke-0 sampai jam ke-8. Sedangkan pada fase log, pertumbuhan bakteri sangat cepat karena nutrisi yang tersedia masih mencukupi. Selama fase ini bakteri tumbuh pada kecepatan maksimum. Fase log terjadi pada jam ke 12 sampai jam ke 18. Setelah mengalami peningkatan jumlah sel yang tinggi, maka kebutuhan 
makanan bakteri akan berkurang. Oleh karena itu, sebagian bakteri akan mengalami kematian karena kekurangan nutrisi sehingga bakteri berada pada titik kejenuhan yang disebut fase statisoner. Jumlah bakteri yang hidup dan mati akan sama sehingga jumlahnya terlihat konstan. Fase ini terjadi pada jam ke-20 hingga jam ke-48. Pada Gambar.1 tidak terdapat fase kematian Lactobacillus bulgaricus karena kurangnya waktu inkubasi. Namun, jika waktu inkubasi diperpanjang melebihi 48 jam dapat dimungkinkan terjadi fase kematian. Karena setelah 48 jam, bakteri yang mengalami fase kematian ditunjukkan dengan penurunan jumlah sel. Hal ini dikarenakan nutrisi yang ada pada media sangat rendah sehingga mengakibatkan tidak ada pertumbuhan bakteri lagi (Waluyo, 2004). Waktu pertumbuhan optimal dalam pertumbuhan Lactobacillus bulgaricus yaitu selama 16 jam.

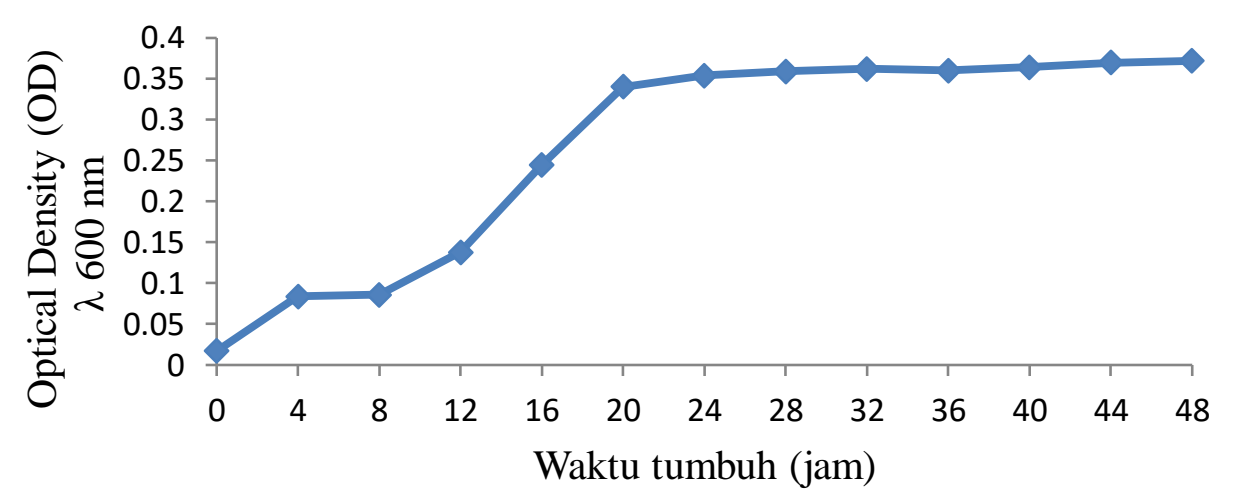

Gambar 1. Kurva pertumbuhan Lactobacillus bulgaricus

Tabel 1. kadar protein yang terhidrolisis oleh Lactobacillus bulgaricus

\begin{tabular}{ccccc}
\hline No & Perlakuan media & $\begin{array}{c}\text { Protein awal } \\
\text { jam ke-0 }(\mu \mathrm{g} / \\
\mathbf{m L})\end{array}$ & $\begin{array}{c}\text { Protein } \\
\mathbf{s i s a} \mathbf{j a m} \\
\mathbf{k e - 1 8}(\mu \mathrm{g} / \\
\mathbf{m L})\end{array}$ & $\begin{array}{c}\text { Protein yang } \\
\text { terhidrolisis } \\
(\mu \mathbf{g} / \mathbf{m L})\end{array}$ \\
\hline 1. & +BSA1 $\mu \mathrm{g} / \mathrm{mL}$ & 6,16 & 4,4 & 1,76 \\
2. & +ampas tahu 1 gram & 8,58 & 5,4 & 3,18 \\
\hline
\end{tabular}

Uji Aktivitas Protease Dari Probiotik Lactobacillus bulgaricus.

Lactobacillus bulgaricus dapat mengeluarkan protease dari dalam sel keluar lingkungan tumbuhnya dengan bantuan induser, sehingga dapat diuji aktivitas proteasenya. Nilai absorbansi yang terbaca pada jam ke-0 dan jam ke-18, dimasukkan kedalam regresi kurva standar BSA sebesar $y=0,025 x+0,125$. Kurva standar BSA digunakan untuk menghitung kadar protein yang terhidrolisis. Data ditampilkan pada Tabel 1.
Berdasarkan Gambar 2 dapat dijelaskan bahwa media biakan dengan tambahan BSA yang awalnya memiliki kadar protein $6,16 \mu \mathrm{g} / \mathrm{mL}$, oleh probiotik Lactobacillus bulgaricus dapat dihidrolisis sebesar 1,76 $\mu \mathrm{g} / \mathrm{mL}$. Sedangkan pada media biakan yang mengandung pakan ampas tahu yang awalnya memiliki kadar protein 8,58 $\mu \mathrm{g} / \mathrm{mL}$ oleh probiotik dihidrolisis sebesar $3,18 \mu \mathrm{g} / \mathrm{mL}$. Hal ini sesuai dengan prinsip kerja probiotik yang menunjukkan bahwa Lactobacillus bulgaricus memiliki kemampuan menghidrolisis protein kompleks yang terdapat pada masing- 
masing media biakan menjadi protein yang lebih sederhana.

Untuk mengecek ada tidaknya protease yang dihasilkan oleh probiotik, supernatan pada waktu inkubasi 18 jam dilakukan uji aktivitas protease (Enggel et al., 2004). Uji aktivitas protease menggunakan metode hidrolisis substrat (kasein) oleh protease menggunakan metode Bradford. Substrat yang ditambahkan, diukur nilai absorbansinya terlebih dahulu menggunakan metode Bradford sehingga diperoleh kadar protein sebesar 39,4 $\mu \mathrm{g} /$ mL. Aktivitas protease oleh probiotik Lactobacillus bulgaricus, dapat ditampilkan pada Tabel 2.

Unit aktivitas protease didefinisikan banyaknya enzim yang dapat menghidrolisis $1 \mu \mathrm{g} / \mathrm{mL}$ protein per menit pada kondisi percobaan. Berdasarkan Gambar 3 dapat dijelaskan bahwa media biakan yang mengandung BSA memiliki aktivitas protease sebesar 133,28 U/mL.
Sedangkan pada media biakan yang mengandung pakan ampas tahu memiliki aktivitas protease sebesar 131,04 U/mL. Protease adalah enzim penghidrolisis protein menjadi senyawa-senyawa yang lebih sederhana seperti peptide atau asam amino (Bergman, 1942). Adanya protease tesebut dapat ditunjukkan dari besarnya nilai aktivitas protease yang terdapat pada masing-masing media biakan. Aktivitas protease pada media yang mengandung BSA hanya selisih 2,24 U/mL dari aktivitas protease pada media pakan ampas tahu. Hal ini menunjukkan bahwa pakan ampas tahu yang dianggap limbah, jika dicampurkan probiotik Lactobacillus bulgaricus memiliki aktivitas protease yang tidak jauh berbeda dengan tambahan BSA. Sehingga Lactobacillus bulgaricus dapat digunakan sebagai probiotik dalam tambahan pakan ampas tahu karena mampu menghasilkan protease.

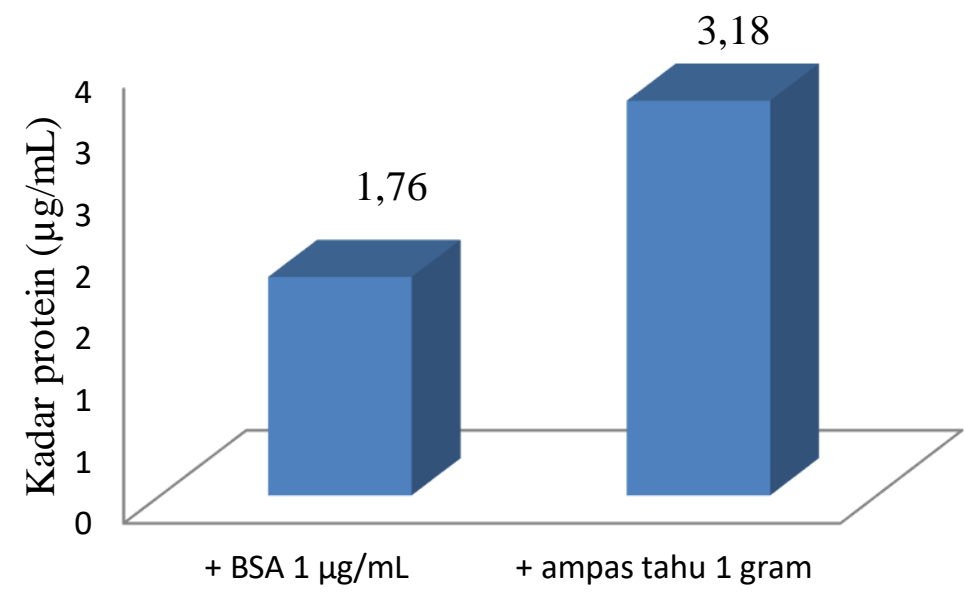

Gambar 2. Kadar protein terhidrolisis oleh probiotik

Optimasi konsentrasi dan waktu fermentasi optimum probiotik Lactobacillus bulgaricus pada pakan ampas tahu.

Data masing-masing hasil optimasi dapat ditampilkan pada Gambar 4. Grafik variasi konsentrasi menunjukkan adanya penurunan kadar protein terhadap waktu fermentasi dari jam ke-0 sampai jam ke20. Hasil regresi dari masing-masing variasi konsentrasi juga menunjukkan nilai negatif yang berarti telah terjadi degradasi protein kompleks yang terdapat pada pakan ampas tahu menjadi asam-asam amino yang lebih sederhana dengan adanya protease. Konsentrasi optimum probiotik Lactobacillus bulgaricus ditentukan berdasarkan hasil regresi yang memiliki nilai slope paling besar yang menunjukkan adanya laju penurunan kadar protein. Dari kelima variasi OD probiotik Lactobacilus bulgaricus, probiotik OD 0,6 
yang memiliki kriteria yang sesuai yakni memiliki regresi sebesar $\mathrm{y}=-0.413 \mathrm{x}+$ 6.568. Sehingga probiotik OD 0,6 dianggap sebagai konsentrasi probiotik optimum. Sedangkan waktu fermentasi optimum pada pakan ampas tahu, juga ditentukan berdasarkan Gambar 4 yakni terjadi penurunan kadar protein sisa berturut-turut dari waktu ke waktu. Fermentasi pakan ampas tahu yang optimum berada pada jam ke-16. Pada jam tersebut terjadi penurunan yang signifikan

Selama fermentasi, pakan ampas tahu yang dicampur dengan probiotik Lactobacillus bulgaricus juga dianalisis sifat fisiknya yang meliputi tektur, bau dan warna. Tekstur pakan ampas tahu sebelum fermentasi yaitu kasar dan sedikit padat. Sedangkan selama fermentasi pakan ampas tahu menjadi lunak dan berair. Dari segi bau, pakan ampas tahu awalnya berbau tidak sedap ditunjukkan dengan $\mathrm{pH}$ 7, setelah difermentasi $\mathrm{pH}$ nya turun menjadi 5 dan tidak menghasilkan bau yang menyengat karena danya senyawa metabolit sekunder yang dihasilkan oleh probiotik. Sedangkan warna pakan ampas tahu sebelum fermentasi berwarna putih pucat, namun selama proses fermentasi pakan ampas tahu menjadi putih kekuningan.

Tabel 2. Uji aktivitas protease

\begin{tabular}{lccccc}
\hline No & $\begin{array}{c}\text { Perlakuan } \\
\text { media }\end{array}$ & $\begin{array}{c}\text { Protein } \\
\text { substrat } \\
(\mathbf{k a s e i n}) \\
\mu \mathbf{g} / \mathbf{m L}\end{array}$ & $\begin{array}{c}\text { Protein } \\
\text { sisa } \\
(\mu \mathbf{g} / \\
\mathbf{m L})\end{array}$ & $\begin{array}{c}\text { Protein yang } \\
\text { terhidrolisis } \\
\text { protein substrat- } \\
\text { protein sisa) } \\
(\mu \mathbf{g} / \mathbf{m L})\end{array}$ & $\begin{array}{c}\text { Aktivitas } \\
\text { protease } \\
(\mathbf{U} / \mathbf{m L})\end{array}$ \\
\hline 1. & $\begin{array}{c}\mathbf{+ B S A} \\
1 \mu \mathrm{g} / \mathrm{mL}\end{array}$ & 39,4 & 1,320 & 38,08 & 133,28 \\
\hline $\begin{array}{c}\text { +ampas tahu } \\
1 \text { gram }\end{array}$ & 39,4 & 1,960 & 37,44 & 131,04 \\
\hline
\end{tabular}

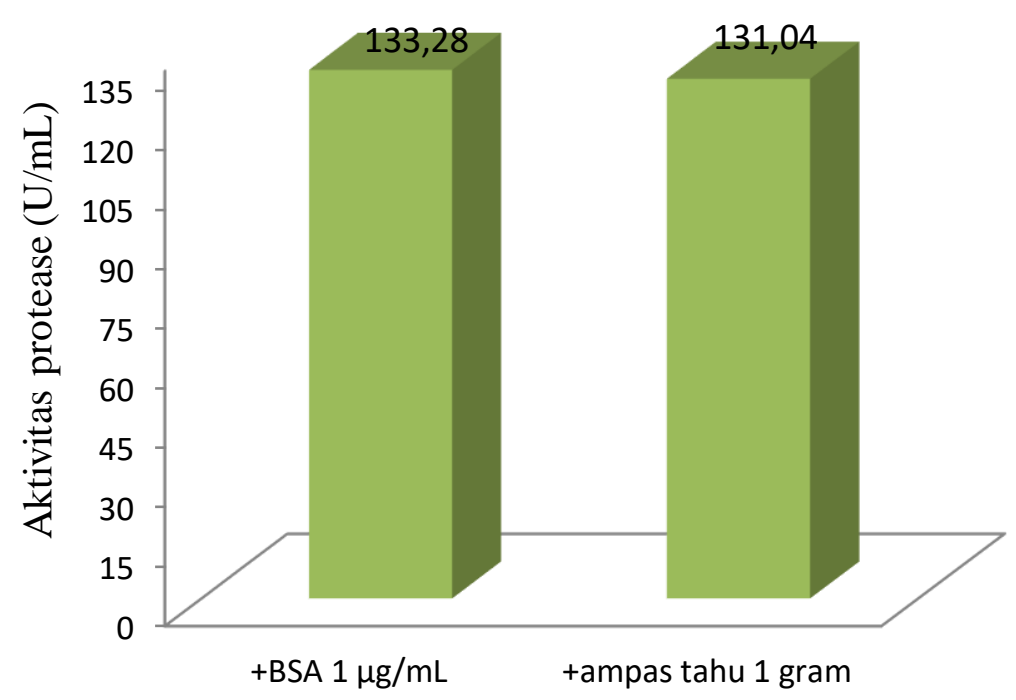

Gambar 3. Aktivitas protease Lactobacillus bulgaricus

Uji Kinerja Probiotik Pada Cacing Tanah.

Uji ini dilakukan berdasarkan kondisi optimasi konsentrasi dan waktu fermentasi pada pakan ampas tahu, yaitu probiotik
Lactobacillus bulgaricus OD 0,6 dan waktu fermentasi 12 jam. Pertumbuhan cacing tanah, diamati selama 16 hari. Setelah 16 hari,cacing tanah ditimbang 
kembali beratnya untuk mengetahui efek probiotik Lactobacillus bulgaricus dalam peningkatan produktivitas cacing tanah.
Persen kenaikan berat cacing tanah dapat ditunjukkan pada Gambar 6.
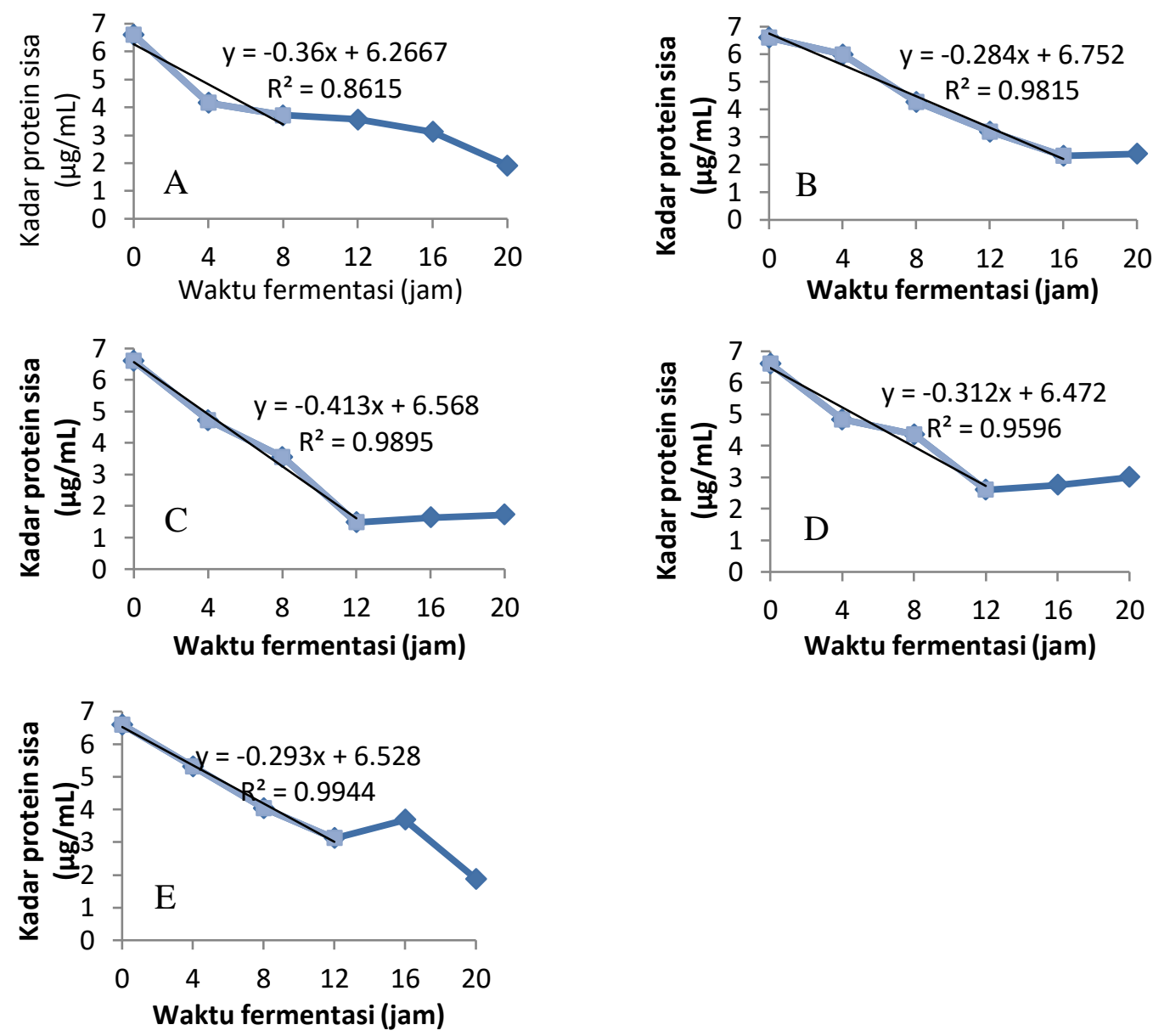

Gambar 4. Grafik pengaruh jumlah Lactobacillus bulgaricus (diwakili dengan OD) terhadap degradasi protein ampas pada berbagai waktu fermentasi. A (OD 0,2); B (OD 0,4); $\mathrm{C}(\mathrm{OD} 0,6) ; \mathrm{D}(\mathrm{OD} 0,8) ; \mathrm{E}(\mathrm{OD} 1)$
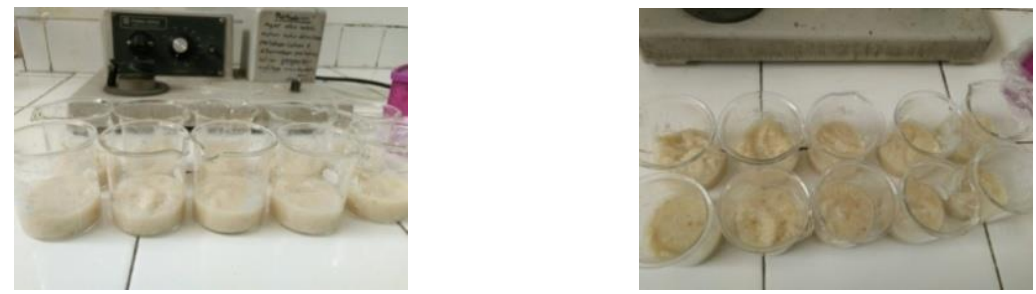

Gambar 5. Kondisi pakan ampas tahu sebelum fermentasi (kiri) dan kondisi pakan ampas tahu setelah fermentasi (kanan).

Pertambahan berat cacing tanah dapat terlihat dari selisih antara berat cacing tanah pada hari ke- 0 sebelum pemberian pakan hingga 16 hari setelah pemberian pakan. Pada Gambar 6 dan 7 menunjukkan bahwa kenaikan berat cacing tanah pada pakan ampas tahu yang mengandung probiotik lebih tinggi daripada berat cacing tanah yang hanya diberikan umpan pakan ampas tahu.

Selama proses fermentasi, kondisi pakan ampas tahu juga diamati yang meliputi bau. Bau pakan ampas tahu yang dicampur dengan probiotik Lactobacillus 
bulgaricus yang umumnya berbau tidak sedap, namun selama fermentasi pakan ampas tahu tidak berbau sehingga ramah lingkungan. Hal ini dikarenakan Lactobacillus bulgaricus mampu menghasilkan senyawa metabolit sekunder sehingga kemungkinan adanya bakteri pathogen lain menjadi sedikit. Selain itu, pakan ampas tahu yang dicampur probiotik Lactobacillus bulgaricus lebih cepat habis dimakan cacing tanah dibandingkan dengan hanya diberikan pakan ampas tahu. Enzim protease yang dihasilkan oleh probiotik mampu memecah molekul kompleks pakan ampas tahu menjadi molekul yang sederhana sehingga mudah dicerna oleh usus cacing tanah. Dengan demikian, pakan ampas tahu selain sebagai limbah juga sebagai sumber protein dan dapat dimanfaatkan sebagai pakan cacing tanah yang berkualitas dengan tambahan probiotik Lactobacillus bulgaricu

Tabel 3 Kenaikan berat cacing tanah

\begin{tabular}{cccccc}
\hline \multicolumn{2}{c}{ Perlakuan } & \multicolumn{2}{c}{$\begin{array}{c}\text { Berat cacing tanah } \\
\text { pada hari ke- } \\
\text { 0 }\end{array}$} & $\begin{array}{c}\text { Selisih berat } \\
\text { (gram) }\end{array}$ & $\begin{array}{c}\text { \% kenaikan } \\
\text { berat }\end{array}$ \\
\hline $\begin{array}{c}\text { Media } \\
\text { pakan }\end{array}$ & ampas tahu & $250 \mathrm{~g}$ & $285 \mathrm{~g}$ & 35 & $14 \%$ \\
$\begin{array}{c}\text { yang } \\
\text { ditambah } \\
\text { dengan- }\end{array}$ & $\begin{array}{c}\text { ampas } \\
\text { tahu+probiotik }\end{array}$ & $250 \mathrm{~g}$ & $\begin{array}{c}375 \mathrm{~g} ; \\
380 \mathrm{~g} ;\end{array}$ & 118,33 & $32,13 \%$ \\
\hline
\end{tabular}

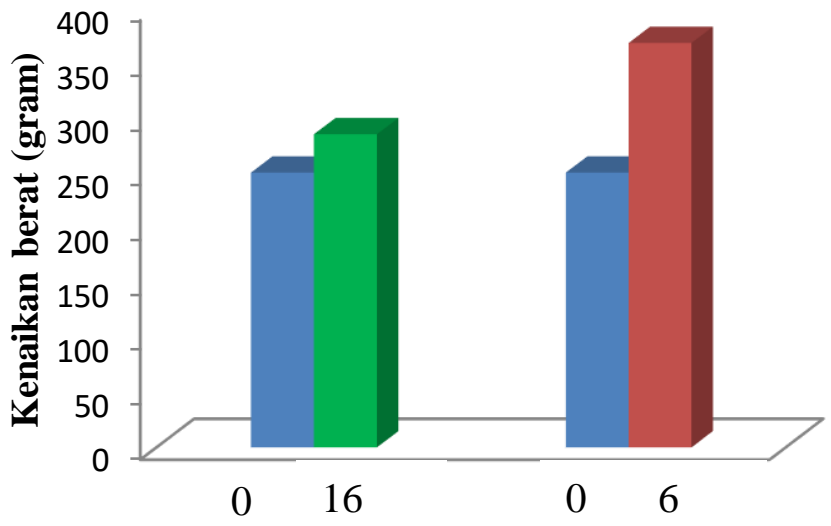

Hari ke-
- Kontrol berat cacing awal

- Cacing tanah dengan pakan ampas tahu

Cacing tanah dengan pakan ampas tahu+probiotik

Gambar 6. Grafik kenaikan berat cacing tanah setelah diberikan pakan ampas tahu yang dicampur dengan probiotik Lactobacillus bulgaricus 


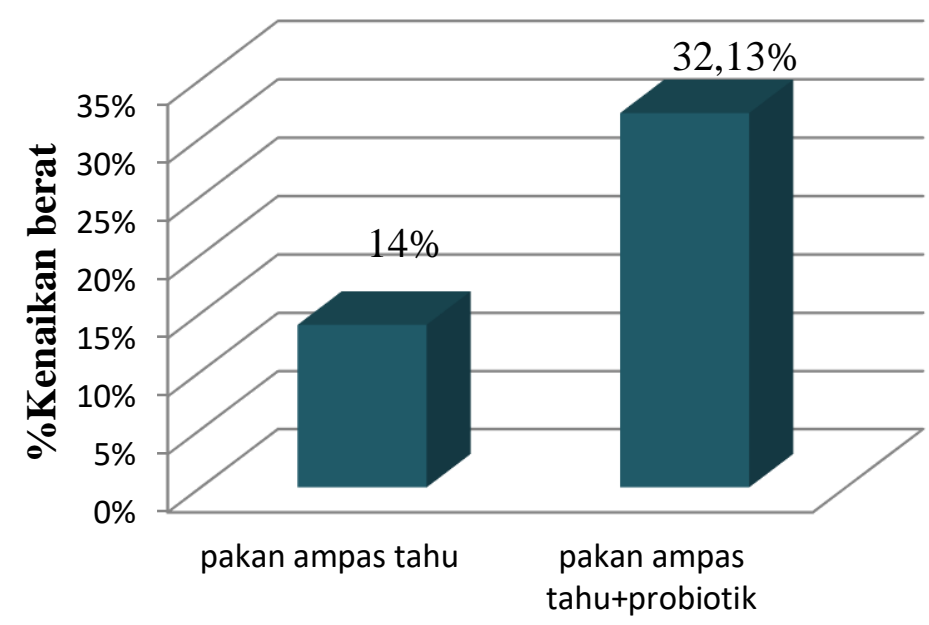

Gambar 7. Grafik persen kenaikan berat cacing tanah

\section{Kesimpulan}

Lactobacillus bulgaricus dapat menghasilkan protease pada media yang mengandung BSA dengan aktivitas protease sebesar 133,28 U/mL. Sedangkan pada media yang mengandung pakan ampas tahu diperoleh aktivitas protease sebesar 131,04 U/mL. Lactobacillus

\section{Daftar Pustaka}

Bradford, M., M., 1976. A rapid and sensitive method for quantitation of protein utilization. The principle of protein-dye binding. Anal. Biochem. 72, 248-254

Bergman, M., 1942. A classification of proteolytic enzymes. Adv. Enzimol

Effendi, I. 2002. Probiotics for Marine Organism Disease Protection. Pekanbaru: Fakultas Perikanan dan Ilmu Kelautan Universitas Riau.

Enggel, J., Meriandini, A. and Natalia, L., 2004. Karakterisasi Protease Ekstraseluler Clostridiun bifermentans R14-1-b. Jurnal Mikrobiologi Indonesia, 9, 9 - 12. bulgaricus OD 0,6 dapat mencerna ampas tahu secara optimal untuk pakan cacing tanah selama 12 jam. Probiotik Lactobacillus bulgaricus yang dicampurkan kedalam pakan ampas tahu, mempengaruhi berat cacing tanah dengan prosentase kenaikan berat sebesar 32,13\%.

FAO/WHO. 2001. Joint FAO/WHO Expert Consultation on Evaluation of Health and Nutritional Properties of Probiotics in Food Including Powder Milk with Live Lactic Acid Bacteria. Amerian Córdoba Park Hotel, Córdoba, Argentina

Kompiang, I., P., 2009. Pemanfaatan Mikroorganisme sebagai Probiotik untuk Meningkatkan Produksi Ternak Unggas di Indonesia. Pengembangan Inovasi Pertanian : Bogor. Hal 188 Waluyo, 2004, Mikrobiologi Umum. Universitas Muhammadiyah Press, Malang 